\title{
りん酸形燃料電池用水蒸気改質触媒の評価
}

\author{
正貝 堀田和孝 正員小川賢 (関西電力) \\ 非会員 三好英明 非会員 都留 潔 (三菱電機)
}

\section{Experimental Study of Reforming Catalyst on Phosphoric Acid Fuel Cell Plant}

Kazutaka Hotta Member , Masaru Ogawa Member (Kansai Electric Power Co.,Inc.)

Hideaki Miyoshi Non-Member, Kiyoshi Tsuru Non-Member (Mitsubishi Electric Corp.)

\begin{abstract}
Hydrogen production of petroleum technology was applied to reforming technology on PAFC. Pressure of the petroleum plants were not atmospheric but high. So petroleum technologies could not applied directly PAFC reforming condition. For this reason, we observed behavoir of catalyst which is most influenced on reforming ability. Generally, decline of catalytic ability was caused by three phenomenons : sulfur poisoning, carbon deposition and sintering. Sulfur poisoning was well known to decrease catalytic activity, but regeneration methods did not be reported in detail under PAFC reforming condition yet. And other phenomenons, carbon deposition and sintering, were prevented by best choise of catalyst on the market to be suitable for operating conditions. But to be compared these catalysts with the same condition did not be reported yet, too. For pressed comercialization of PAFC, we experimented with micro reactor to observe regeneration of sulufur poisoned catalysts and to compare of carbon deposition and sintering with two type $\mathrm{Ni}$ catalysts under PAFC conditions. And we could observed that best condition of regeneration and influence of catalytic support's compound on carbon deposition and sintering.
\end{abstract}

キーワード：りん酸形燃料電池, 改質触媒, 硫黄被毒, 硫黄除去, シンタリング, カーボン析出, 反応速度定数

\section{1.まえがき}

りん酸形燃料電池（以下 PAFC）は、従来の発電荬置と 比へ騒音やSOx,NOxの発生が少なく、排熱を利用すれば 総合効率 70\%以上が期待できることから、街中の需要サ イト近傍へ設置できる発電システムとして実用化が期待さ れている。このような電熱利用の形態をねらいとした PAFCの実証研究が開始され約 10 年経過するが、まだ信 頼性の面で十分とは言えない。この信頼性低下に大きく影 響を及ほしているのがセルスタック本体のトラブルであり、 この部分にトラブルが発生すると、セルスタックに多額の 修理費用と長期の発電停止期間が生じる。このセルスタッ クのトラブルは、セルスタックを構成するカーボン材の腐 食や、極間クロスオーバー、冷却水漏れなどが原因として 挙げられる。筆者らは、P A F C の実証運転で、改質器の 性能低下に起因したセルスタックのトラブルを経験した。 水素ガスの供給不足がカーボン材を腐食させるメカニスム は明らかにされている(1)(2)ものの、改質器の性能低下に ついて報告された例がなく、本研究でその要因を調查した。
PAFCの改質ブロセスには、石油工業界の水素製造で培 われたスチームリフォーミング技術が適用されている。石 油工業界において本技術に関する報告 (3) は多々あるが、 大規模プラントの加圧条件下で使用されたものであり、常 圧で使用する PAFC 改質器に適用するには土夫が必要であ る。

一般に、改質性能の低下要因には、改質触媒の硫黄被毒、 カーボン析出、シンタリングが挙げられる(4)。硫黄被毒 については、以前からその影響の大きさは知られており (5)、 被毒後ただちに硫黄除去する必要がある。また、カーボン 析出とシンタリングの問題は、使用雾囲気に合った触媒を 選定することが重要である。しかし、これら分野の報告例 がないのが現状である。

本研究では、これらの問題を解決するため、改質触媒試 験装置を用いて、硫黄除去方法の検証を行うとともに、市 販 Ni 触媒の耐カーポン性と耐シンタリング性の試験を行 い触媒の選定，評価に関する知見を得たので報告する。 


\section{PAFC改筫器の概要}

図 1にPAFCのシステムフローを示す。原然料の $\mathrm{CH}_{4}$ (都市ガス 13A) は、改質器で $\mathrm{H}_{2}$ に変换され、セルスタッ クへと供給される。セルスタックでは、 $\mathrm{H}_{2}$ と空気 $\left(\mathrm{O}_{2}\right)$ により DC 電力を発電して、インバーターにより $\mathrm{AC}$ 電力 を負荷へ供給する。また、セルスタックと改質器で発生し た余剩熱は、排熱回収䒾監により熱負荷へと供給される。

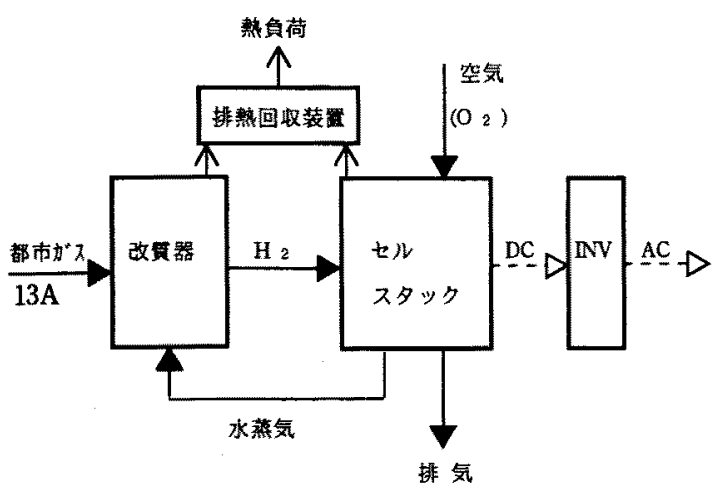

図 1.PAFCのシステムフロー

Fig.1. Schematic diagram of PAFC

改質器では都市ガス中のメタン $\left(\mathrm{CH}_{4}\right)$ と添加した水 蒸気（ $\mathrm{H}_{2} \mathrm{O} ） に よ り(1)$ 式のような水蒸気改質反応が生 ずる。この (1) 式で生じた COは、(2) 式のような CO 転化 反応を順次生じる(日)。また、実幾の改質器触媒層の温度 分布は、ガスの流れ方向に沿って $500 \sim 800^{\circ} \mathrm{C} の$ 温度プロ フィールとなるよう設計されている。

$\mathrm{CH}_{4}+\mathrm{H}_{2} \mathrm{O} \Leftrightarrow \mathrm{CO}+3 \mathrm{H}_{2} \quad \Delta \mathrm{H}=49.3 \mathrm{kcal} / \mathrm{mol}$

$\mathrm{CO}+\mathrm{H}_{2} \mathrm{O} \Leftrightarrow \mathrm{CO}_{2}+\mathrm{H}_{2} \quad \Delta \mathrm{H}=-9.8 \mathrm{kcal} / \mathrm{mol}$

\section{3. 試験方法}

\section{$\langle 3 \cdot 1\rangle$ 試験装置}

本矿究で使用した改貿触媒試験置（電気式マイクロリ アクター)の概要を図 2 に示す。原然料には、低圧供給の 都市ガス 13A を使用して、脱硫機能を有する昇王装置か ら原然料を試験装置へと供給している。水蒸気改質に使用 する水蒸気は気化器へ純水を供給して、原然料に添加して いる。また、反応管の大きさは内径 $22 \mathrm{~mm}$, 有効加熱長さ $500 \mathrm{~mm}$ であり、電気炉内の温度は最高 $1000^{\circ} \mathrm{C}$ まで制御が 可能である。

$\langle 3 \cdot 2\rangle$ 供試触媒

供試触媒は、市販の Ni 触媒の中で、製造メーカーと担 体成分の異なる 2 種類の触媒（表 1) を選定した。

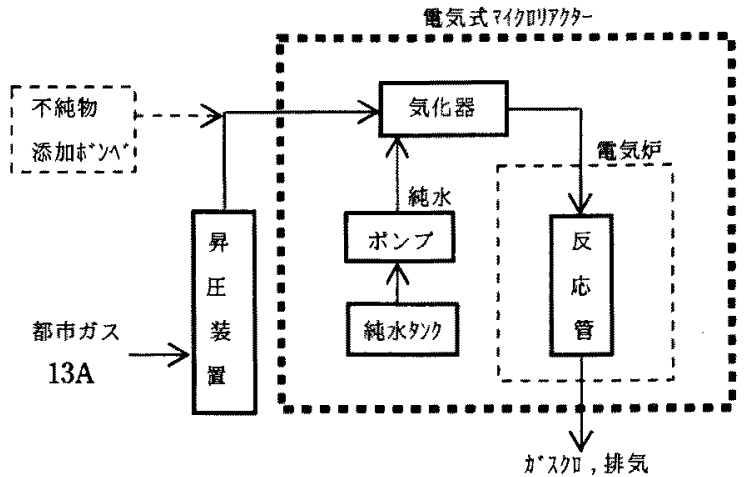

图2. 改質触媒試験装置のシステムフロー

Fig.2. Schematic diagram of Micro Reactor

表 1 供試触媒

Table 1. Components of experimental catalysts

\begin{tabular}{|c|l|c|}
\hline 觖号 & 触媒金属 & 担体種類 \\
\hline $\mathrm{A}$ & $\mathrm{Ni} 12 \mathrm{wt} \%$ & $\mathrm{Al}_{2} \mathrm{O}_{3}$ \\
\hline $\mathrm{B}$ & $\mathrm{Ni} 15 \sim 17 \mathrm{wt} \%$ & $\mathrm{MgO}^{-\mathrm{Al}_{2} \mathrm{O}_{3}}$ \\
\hline
\end{tabular}

〈3·3〉改質触媒の活性評価指標

改質触媒活性の評価には、粒子内のガス拉散性と活性点 上の反応性を総合評洒できるものとして、下記に定義する 反底速度定数を考案した。

（反応速度定数の定義）

いま、A $\rightarrow$ Bを生じる反応を考えた場合、反応速度 $\mathrm{r}$ は次式となる。

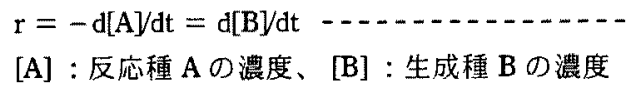

反応速度 $\mathrm{r}$ は濃度に依存し、反㤁の進行にともなって濃度 が変化するため、時間とともに反応速度 $\mathrm{r}$ は変化する。も し、反応速度が濃度 $[\mathrm{A}] 01$ 乗に比例するとすれば、(4) 式が成立ち、時間によって変化する反応速度 $\mathrm{r}$ を時間に無

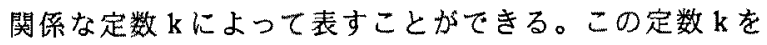
反応速度定数と呼宁。

$$
-\mathrm{d}[\mathrm{A} V \mathrm{~d} \mathrm{t}=\mathrm{k}[\mathrm{A}]
$$

水蒸気改質反応の場合、反応速度式は種々のものが報告さ れており ${ }^{(3)}$ 定説はないが、 $\left[\mathrm{CH}_{4}\right]$ ○1 次に比例する点 は、どの報告も一致している。そこで、改質反応の速度式 を(5) 式として反応速度定数 $\mathrm{k}$ 求め、触媒能力の評価指 標とした。

$$
\mathrm{r}=\mathrm{k}\left[\mathrm{CH}_{4}\right]
$$

ここで定義した反応速度定数 $\mathrm{k}$ は、次章以降の触媒活 性を示す評価值として、触媒ことに活性試験を行い、単位 時間，単位重量(触媒) あたりの $\mathrm{CH}_{4}$ 消費量（反応速度） 
と $\mathrm{CH}{ }_{4}$ 濃度から反応速度定数 $\mathrm{k}$ を求めた。

\section{4. 実験と結果}

$\langle 4 \cdot 1\rangle$ 硫黄除去

硫黄被毒は、通常の運転では、脱硫器の存在により、硫 黄分が改質器に供給されることはない(7)。しかし、時に は、システム制御の異常などにより、脱硫器の能力が低下 し、原燃料中に含まれる硫黄分が一部改質器に漏れ込むこ ともあり得る。また、脱硫後の硫黄濃度を連続的に計測監 視することは、濃度が微量（0.1ppm 以下）であることか ら困難であり、脱硫器から硫黄分が漏れだした場合、これ を検知して改質触媒の硫黄被瑇を未然に防ぐことは難しい。 一旦、改質触媒が硫黄被毒された場合、触媒性能が低下し、 セルスタック本体へ影響を及ぼすことになる。また、硫黄 被毒した触媒にカーボン析出を生じる報告 (5)もあり、改 質器自体にとっても梁刻な問題となる。燃料電池用のコン パクトタイプの改質器においては、改質触媒の交換は容易 でないため、万一、硫黄被毒を生じた場合に、硫黄除去技 術が不可欠となる場合があり、本章では、赛機へ適用可能

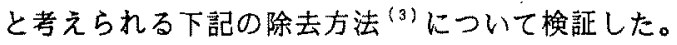

\section{（1）スチーミングによる硫黄除去}

硫黄被毒した触媒にスチームを供給することにより、 次式の反応で硫黄分を除去する方法。

$$
\text { 触媒 }-\mathrm{S}+\mathrm{H}_{2} \mathrm{O} \rightarrow \text { 触媒 }-\mathrm{O}+\mathrm{H}_{2} \mathrm{~S} \cdots \cdots(\text { (6) }
$$$$
\mathrm{H}_{2} \mathrm{~S}+2 \mathrm{H}_{2} \mathrm{O} \rightarrow \mathrm{SO}_{2}+3 \mathrm{H}_{2} \cdots \cdots-(7)
$$

（2）改質運転による硫黄除去

硫黄の流入さえ止まれば、改質運転を継続することに より、次式の反応で触媒表面に吸着した硫黄を硫化水素 として除去する方法。

触媒 $-\mathrm{S}+\mathrm{H}_{2} \rightarrow$ 触媒 $+\mathrm{H}_{2} \mathrm{~S}-\ldots-\ldots(8)$

以下にそれそれの検証結果を示す。

$\langle 4 \cdot 1 \cdot 1\rangle$ 硫黄被毒触媒の作製

硫黄被毒触媒の作製条件を表 2 に示し、図 3 には硫黄投 入量に対する硫黄付着量と触媒活性の関係を示す。図3で

\section{表2 硫黄被毒触媒の作製条件}

Table 2. Experimental condition of making sulfur-poisoned catalyst

\begin{tabular}{|c|c|}
\hline 触媒 & $\mathrm{A}$ 触媒 $10 \mathrm{~g}_{(}\left(\mathrm{H}_{2}\right.$ 要元済み) \\
\hline 供給ガス & 都市カ广ス 500ce/min \\
\hline 硫黄湭度 & 1 volppi \\
\hline 温度 & $450^{\circ} \mathrm{C}$ \\
\hline$S / C$ & $2.5($ 沵加水 $1.2 \mathrm{cc} / \mathrm{min})$ \\
\hline 硫黄付着時閏 & $20,50,250$ 時間 \\
\hline
\end{tabular}

は、嚾か 1volppm の硫黄スリップでも 20 時間継続で 60\%， 50 時間で $40 \%$ に触媒活性が低下しており、硫黄被毒が短 時間で大きな活性低下を及ぼすことを示している。

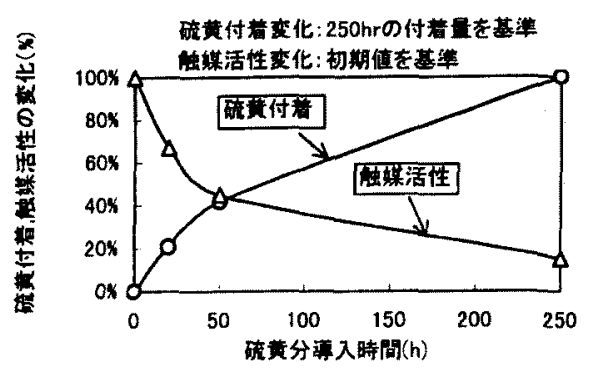

图 3 硫黄投入量に対する硫黄付着量と触媒活性の関係

Fig. 3. Relation of sulfur adsorption, catalytic activity toward sulfur addition stream

\section{$\langle 4 \cdot 1 \cdot 2\rangle$ 硫黄除去効果}

次に、スチーミングと改質運転の硫黄除去効果を調へた。 供試触媒には 150wtppm 硫黄付着した触媒サンプルを使用 している。それぞれの試験条件を表 3 と表 4 に示す。

\section{表 3 スチーミング除去条件}

Table 3. Experimental condition of regeneration in steaming

\begin{tabular}{|c|c|}
\hline 触媒 & 硫黄付着150wtppn触媒 $4 \mathrm{~g}$ \\
\hline スチーム流量 & $1600 \mathrm{cc} / \min ($ 添加水 $1.28 \mathrm{cc} / \mathrm{min}$ ) \\
\hline 窒素流量 & $400 \mathrm{cc} /$ min \\
\hline 温度 & $450^{\circ} \mathrm{C} \quad 600^{\circ} \mathrm{C} 750^{\circ} \mathrm{C}$ \\
\hline 除去時間 & 10時間,100時閶 \\
\hline
\end{tabular}

表4 改質除去条件

Table 4. Experimental condition of regeneration in reforming

\begin{tabular}{|c|c|}
\hline 然媒 & 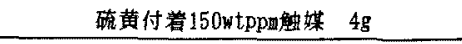 \\
\hline スチーム流眐 & $1125 \mathrm{cc} / \mathrm{min}($ 添加水 $0.90 \mathrm{cc} / \min , \mathrm{S} / \mathrm{C}=2.5$ 相当 $)$ \\
\hline メタン流量 & $450 \mathrm{cc} / \mathrm{min}$ \\
\hline 温度 & $600^{\circ} \mathrm{C} \quad 750^{\circ} \mathrm{C}$ \\
\hline 除去時間 & 100符間 \\
\hline
\end{tabular}

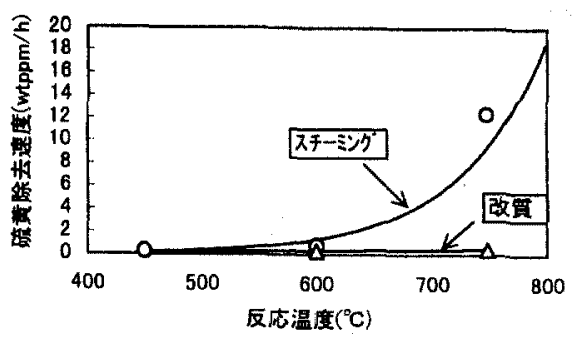

図 4 硫黄除去効果

Fig 4. Influence of steaming/reducing on removing sulfur 
図 4 に硫黄除去効果を示す。スチーミング除去では、温 度上昇とともに除去速度が大きくなる傾向にあったが、改 質除去ではあまり硫黄除去への効果はなく、温度を上昇さ せても殆ど変化がなかった。これらの結果より、硫黄除去 にはスチーミンクが有効であることを確認した。

〈4·2〉カーボン析出

改筫器内の触媒にカーボンが析出すると、触媒活性点を カーボンが要い、反応ガスの桩散が阻害されて、改質性能 低下を引き起こす。さらに、カーボン析出が進行すると、 ガスの流れ自体を閉塞して、プラントの運転に支障をきた す。カーボン析出は、主に原燃料に対する添加水蒸気量 （以下 S/C）の低下が発生原因であるが、添加水蒸気量の 增加は、システム絵合効率の低下と補給水の增加に龂がる ので、可能な限り少ない水蒸気量の運転が望まれる。その ため、触媒メーカーではニッケル触媒の担体にエ夫を加え、 耐カーボン析出性の向上を図っている。これは、カーボン が担体の酸性サイトに析出するとの説 ${ }^{(a)}$ から、担体にア ルカリ成分を添加して、カーボン析出を抑制しているもの である。そこで、本試験では、表 1 に示す担体成分の異な る市販 Ni触媒 2 種類の低 S/C 条件下でのカーボン析出特 性を評価した。

\section{$\langle 4 \cdot 2 \cdot 1\rangle$ 試験条件}

表 5 にカーボン析出試験の条件を示す。この中で、試験

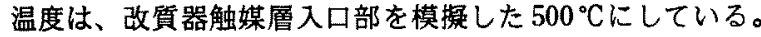
これは、PAFC 改質器の入口部 $\left(500^{\circ} \mathrm{C}\right)$ にカーボンが集 中して析出する実機報告例 (9) があるためである。また、 試験時間の $100 \mathrm{~h}$ については、事前に A 触媒で $200 \mathrm{~h}$ の力 一ボン析出量と同等であることを確認している。

表 5.カーボン析出試験条件

Table 5. Experimental condition of carbon deposition

\begin{tabular}{|c|c|}
\hline 供給ガス & 都市去入 $170 \mathrm{cc} / \mathrm{min}$ \\
\hline 触媒 & $\mathrm{A}, \mathrm{B}$ 触媒 (3g) \\
\hline 温度 & $500^{\circ} \mathrm{C}$ \\
\hline $\mathrm{s} / \mathrm{C}$ & $1.5 \sim 3.5$ \\
\hline 弑酸時間 & $100 \mathrm{~h}$ \\
\hline
\end{tabular}

\section{$\langle 4 \cdot 2 \cdot 2\rangle$ 試験結果}

図 5 に各触媒の $\mathrm{S} / \mathrm{C}$ を変化させた時のカーボン析出特性 を示す。同じ Ni触媒でも担体組成の違いで $\mathrm{S} / \mathrm{C}$ 特性が異 っている。A触媒では $\mathrm{S} / \mathrm{C}=2.5$ を境界にして、カーボンか 急激に析出し、B触媒では $\mathrm{S} / \mathrm{C}=2.0$ で析出が急澈に進行

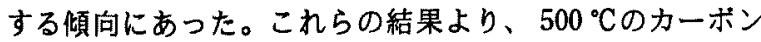
析出限界点は、A触媒が $\mathrm{S} / \mathrm{C}=2.5$ であり、担体にアル力 リ成分を担体に添加した $B$ 触媒では $\mathrm{S} / \mathrm{C}=\mathbf{2 . 0}$ へ改善され ていた。

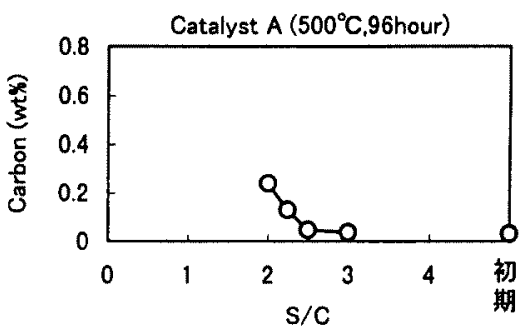

（a）A触媒のカーボン析出特性

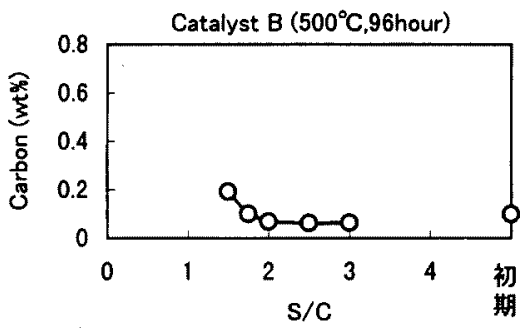

(b) B触媒のカーボン析出特性

図 5 各触媒のカーボン析出特性

Fig. 5 Influence of steam-carbon ratio on carbon deposition

〈4·3〉シンタリング試験

一般に触媒金属のシンタリングは、虽点の $1 / 2$ の温度か ら発生することが知られている(3)。従って、Niの融点が

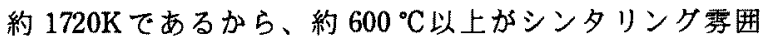
気となる。実機改質器の温度プロフィールが $500{ }^{\circ} \mathrm{C} \sim 800$ ○Cであるため、本試験では、最もシンタリング雾囲気にあ

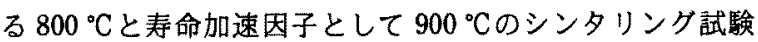
を行った。

\section{$\langle 4 \cdot 3 \cdot 1\rangle$ 試験条件}

シンタリンク試験の条件を表 6 に示す。シンタリング試 験では、長時間の寿命検証を行うため、実機を模擬した雾 囲気にしている。

\section{表6 シンタリング試験条件}

Table 6. Experimental condition of sintering

\begin{tabular}{|l|c|}
\hline 反応温度 & $800,900^{\circ} \mathrm{C}$ \\
\hline 共給ガス & 都市ガス $13 \mathrm{~A}: 250 \mathrm{cC} / \min$ (SVを実機相当) \\
\hline $\mathrm{S} / \mathrm{C}$ & 2.5 (添加水 $0.60 \mathrm{cc} / \mathrm{min})$ \\
\hline 触媒 & $\mathrm{A}, \mathrm{B}$ 触媒 \\
\hline
\end{tabular}

また、 $800{ }^{\circ} \mathrm{C}$ の触媒を評価する場合、実機改質器の出口 部に充填された触媒の雾囲気を模撷する必要があるため、 試験用反応管の充填方法について図6で検討した。ここで、 図 6(a)の充填方法 1では実機と下記の 2 点が相違する。

(1)触媒層入口部で大量の反応が生じる。 
(2)触媒層入口部が、メタン，スチーム過多の雾囲気に あり、実機の雰囲気と大きく異なる。

これらの相違を解決するため、図6(b) の充填方法 2 を 採用した。これは、反応管入口部にガス製造用触媒を入れ、 都市ガスと水蒸気から試験温度における平衡組成に近い改 質ガスを製造し、そのガスが試験用の触媒に供給されるよ うにしている。この場合、ガス雰囲気としては、実機に近 いガス組成が得られる。ただ、シンタリング試験用触媒に 供給されるガスが、既にその温度での平衡組成に近いガス になっているため、シンタリング試験用触媒では、反応は 殆ど起こらない点が実機と異なるが、改質反応は吸熱反応 であり、反応しても高温とならないため、反応量の大小は、 シンタリングにあまり影響しないものと考えた。

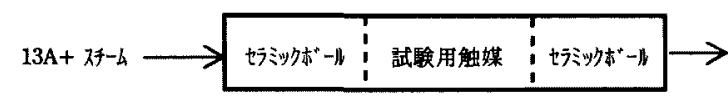

(a) 充填方法 1

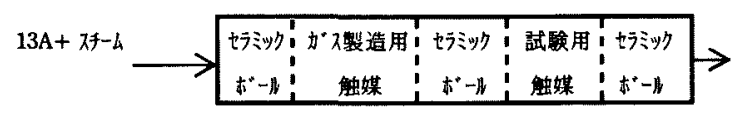

(b) 充填方法 2

図 6. ジ夘ハグ試験の反応管充填方法

Fig. 6 Packing way of catalyst in reactive pipe under sintering test

$\langle 4 \cdot 3 \cdot 2\rangle$ 試験結果

図7に各試験温度におけるシンタリング試験結果を示す。 触媒活性の評価は、反応速度定数を評価時点でそれそれ求 めている。図 7 より、 $900{ }^{\circ} \mathrm{C} の$ 活性低下傾向は、800 ${ }^{\circ} \mathrm{C} に$ 比べて大きく、高温ほど活性低下が大きくなっている。ま た、触媒担体の異なる A,B触媒では、初期の時点では A 触媒に比べB触媒の方が高活性を示したが、3000時間以 降の活性評価では、A,B触媒間で活性に大きな差は認め られない。

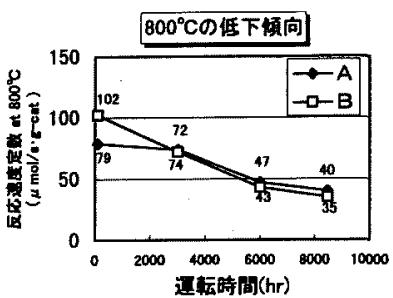

(a) $800{ }^{\circ} \mathrm{C}$ の低下傾向

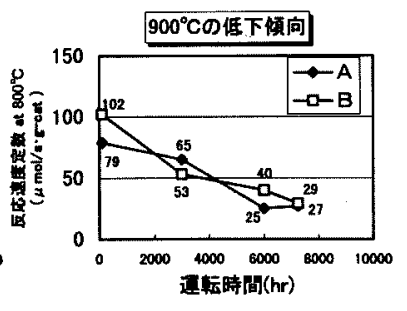

(b) $900{ }^{\circ} \mathrm{C}$ の低下傾向
図 7 シンタリング試験結果

Fig. 7 Influence of temperature on sintering

\section{5. 考察}

（1）硫黄被毒時の除去方法として、前章の図 4 よりスチ 一ミング除去が奻果的であることを検証したが、スチー ミングを行うことで活性低下を起こすことも愁念される。 そこで、硫黄除去後の触媒活性の回復度合いを調查した。 その結果を図 8 に示す。スチーミング除去と改質除去と を比較すると硫黄除去に効果のあったスチーミングが有 効であることが認められた。これは、Ni触媒の反応サ イトに吸着した硫黄が除去されることにより、Ni触媒 の反応可能サイトが回復したためであると考えられる。 たた、 $750{ }^{\circ} \mathrm{C} * 100 \mathrm{~h}$ のスチーミングは、同じ温度の $10 \mathrm{~h}$ に比べ、活性低下を起こしていた。この原因として、シ ンタリングなどの熱的要因が予想される。また、 $450{ }^{\circ} \mathrm{C}$ *100hのスチーミングでは、温度が低すきるため、硫黄 が除去されず殆ど回復効果の無いことを示している。従 つて、本試験結果加ら、 $750^{\circ} \mathrm{C} * 10 \mathrm{~h} ， 600^{\circ} \mathrm{C} * 100 \mathrm{~h}$ 程 度のスチーミンクが効果的に活性回復へ慗がる硫黄除去 条件であることを確認した。

\begin{tabular}{|c|c|}
\hline (1)硫黄被毒触媒 & (5)スチーミンク $450^{\circ} \mathrm{C} * 100 \mathrm{~h}$ \\
\hline 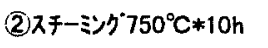 & (6)改䁈 $750^{\circ} \mathrm{C} * 100 \mathrm{~h}$ \\
\hline (3)ステーミング750 $7 * 100 \mathrm{~h}$ & (7)改筫 $600^{\circ} \mathrm{C} * 100 \mathrm{~h}$ \\
\hline (4)スチーシグ600 & (8)新品 \\
\hline
\end{tabular}

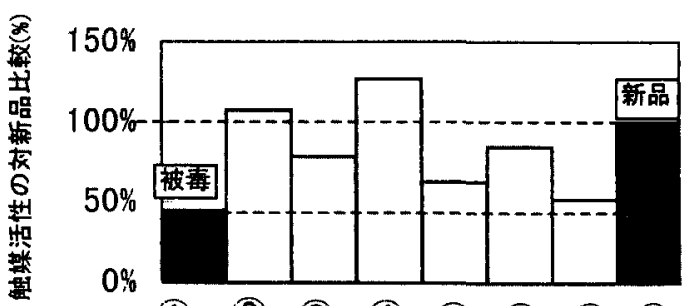

(1) (2) (3) (4) (5) (6) (7) (8)

図 8 硫黄除去による被毒活性回復度合い

Fig. 8 Influence of steaming/reforming on regeneration of catalytic activity

（2）カーボン析出特性について、担体の異なる2 種類の $\mathrm{Ni}$ 触媒を評価した。従来から広く利用されているA触 媒に比ヘ、担体にアルカリ成分 $(\mathrm{MgO})$ を添加した B 触 媒は、カーボン析出限界点が 2.5 から 2.0 に改善されて おり、低 $S / C$ 改質運転の可能性が示唆された。ただ、実 機の運用では、起動停止や負荷変化などで、触媒層内で 過渡的に S/Cの分布を生じる可能性がある。そのため、 実機での S/C 設定値は、どのような運用にもカーボン析 出しない領域で設定することが望まれる。従って、各触 媒のカーボン析出限界点に余裕をもった設定值を適用す る必要があり、本研究て供試した触媒の場合、A触媒 では $\mathrm{S} / \mathrm{C}=3.0 、 B$ 触媒では $\mathrm{S} / \mathrm{C}=2.5$ 程度が実機運用上 
の設定値になると思われる。

（３）シンタリング武験において、B 触媒は A 触媒に比 ヘ、初期活性が高く、3000h までの活性低下が大きくな っている。これは、加圧雾囲気で検証した沼口ら ${ }^{(10)} の$ 報告と同じ結果であり、 $\mathrm{Al}_{2} \mathrm{O}_{3}$ 担体にアルカリ成分を 添加することで、担体の細孔分布が微細化されるが、こ の微細構造は経時的に不安定であるため、初期低下が大 きくなるものと考えられている。

また、 $900{ }^{\circ} \mathrm{C}$ と $800^{\circ} \mathrm{C}$ の活性低下傾向の違いを触媒活 性（反応速度定数）か子約 30 ( $\mu \mathrm{mol} / \mathrm{s} \cdot \mathrm{g}-\mathrm{cat}$ )に到達する 時間で比較すると、 $900{ }^{\circ} \mathrm{C}$ が約 6000 時間、 $800{ }^{\circ} \mathrm{C}$ が約 9000 時間であり、約 1.5 倍の寿命加速効果があることを 検証した。

\section{6. むすひ}

本論文では、主に下記の点を明らかにした。

（1）硫黄被毒による活性低下傾向を確認するとともに、 有効な硫黄除去方法とその最適条件を定量化した。

(2) $\mathrm{Ni}$ 触媒の担体 $\left(\mathrm{Al}_{2} \mathrm{O}_{3}\right)$ にアルカリ成分 $(\mathrm{MgO})$ を 添加した触媒は、 $\mathrm{Ni}^{\prime} / \mathrm{Al}_{2} \mathrm{O}_{3}$ 触媒に比べて、耐カーボン 析出性が向上されていたため、実機での低 S/C 運転の可 能性が示唆されたが、シンタリンクによる活性の初期低 下が大きく、これを見越した設計が必要である。

（3）シンタリング試験では、実機を模擬した雲囲気で、 果積 8400 時間の運転を行い、触媒活性の低下傾向を把 握し、プラント性能監視に必要な基礎データを蓄積する ことができた。

（4）触媒活性低下への温度依存性は、 $900^{\circ} \mathrm{C}$ か $800^{\circ} \mathrm{C} の$ 約 1.5 倍の加速効果があり、触媒選定や寿命予測に役立 つ指標を得ることが出来た。

最後に本研究を遂行するにあたり、試験にこ協力いただ いた関西電力（株）尼崎第三発電所の三好隆氏、関電化工

（株）技術二部の小西君、兼田君に対し、深く感謝の意を 表します。

(平成 11 年 1 月 6 日受付, 同 11 年 4 月 5 日再受付)

$$
\text { 文 献 }
$$

(1) 堤泰行 - 幹淳 - 山口雅教・获本俊明:「リン酸形然 料電池のセル性能および電極損傷に及ぼす反応ガス 直接混合の影響」電学論 $B, 109$ 巻 11 号, 平成元年

(2) 光田憲朗・村橋俊明・松本正昭・宇佐見一雄：「多 極 Reference 付リン酸型燃料電池単セルによるクロス オーバー発生時の腐食挙動の解析」電気化学 61 No.3 (1993)

( 3 ) John R. Anderson and Michel Boudart: "CATALYSIS Science and Technology" Volume5 Springer-Verlag

Berlin Heidelberg New York Tokyo 1984

(4) 松本英之:「固体触媒の劣化と触媒寿命」石油学会 誌第 20 巻第 11 号 (1977)

（5）岡田治 - 田畑健 - 增田正孝 - 松井久次：「硫黄被毒 による触媒劣化」触媒 Vol.35 No.4 (1993)

(6) 岡田治-一本松正道・高見晋・増田正孝-貞森博巳： $\Gamma \mathrm{Ru}$ 系水蒸気改質触媒の硫黄被毒の研究」燃料協会 誌 Vol.68 No.2 (1989)

( 7 ) 岡田治:「高次脱硫技術の開発とその応用」ペトロ テック Vol.20 No.4 (1997)

( 8 ) J.R.Rostrup-Nielsen: " Primary Reforming of Liquid Hydrocarbon Process Field Streams" Ammonia Plant Safety, 15, P82 (1973)

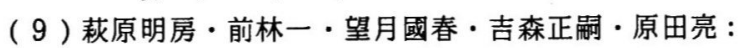
「実機改質触媒の状態と性能評価」第 2 回燃料電池シ ンポジウム A4-4 (1995)

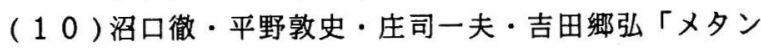
水蒸気改質触媒の活性および炭素析出性の評価」 石油学会誌 39 巻 3 号 (1996)

堀田和孝（正員）1963 年 6 月 12 日生まれ。 84 年

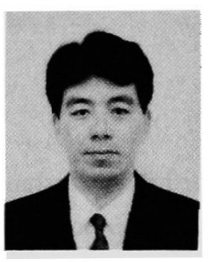
3 月神戸市立工業高等専門学校電気工学 科卒業。同年 4 月関西電力（株）入社。 94 年より総合技術研究所で燃料電池の 研究に従事。

小川賢

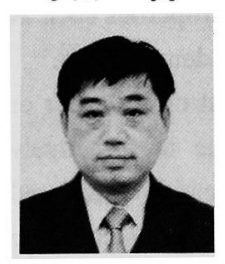

三好 英明

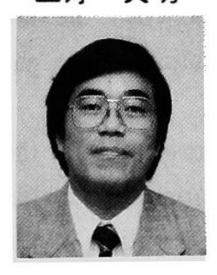

都留 潔

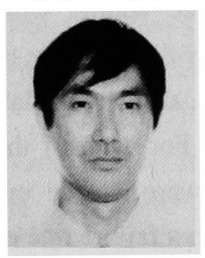

（正員） 1949 年 3 月 9 日生まれ。 72 年 3 月大阪府立大学機械工学科卒業。同年 4 月関西電力（株）入社。 82 年より絵 合技術研究所で燃料電池の研究に従事。

（非会員） 1949 年 9 月 17 日生まれ。 74 年 3 月神戸大学大学院工学研究科修士課 程修了。同年 4 月三菱電機（株）入社。 現在、電力・産業システム事業所にて燃 料電池の研究に従事。

（非会員） 1960 年 8 月 3 日生まれ。 86 年 3 月京都大学大学院工学研究科修士課程 修了。同年 4 月三菱電機入社。以来、電 力・産業システム事業所にて然料電池の 研究に従事。 